\title{
Evaluation of the Properties of Bituminous Concrete Prepared from Brick-Stone Mix Aggregate
}

\author{
Dipankar Sarkar, ${ }^{1}$ Manish Pal, ${ }^{1}$ Ashoke K. Sarkar, ${ }^{2}$ and Umesh Mishra ${ }^{1}$ \\ ${ }^{1}$ Department of Civil Engineering, NIT Agartala, Tripura 799046, India \\ ${ }^{2}$ Department of Civil Engineering, BITS Pilani, Rajasthan 799046, India \\ Correspondence should be addressed to Dipankar Sarkar; dipankarnita@gmail.com
}

Received 22 November 2015; Revised 13 January 2016; Accepted 17 January 2016

Academic Editor: Rui Wang

Copyright (C) 2016 Dipankar Sarkar et al. This is an open access article distributed under the Creative Commons Attribution License, which permits unrestricted use, distribution, and reproduction in any medium, provided the original work is properly cited.

\begin{abstract}
The paper describes an investigation into mechanical properties of brick-stone bituminous concrete mix. The effect of brick-stone mix on various mechanical properties of the bituminous concrete such as Marshall stability, flow, Marshall Quotient (stability to flow ratio), Indirect Tensile Strength, stripping, rutting, and fatigue life of bituminous concrete overlay has been evaluated. In this study over-burnt brick aggregate (OBBA) and stone aggregate (SA) have been mixed in different ratios (by weight) such as $20: 80$, $40: 60,60: 40$, and $80: 20$, respectively. The laboratory results indicate that bituminous concrete, prepared by $20 \%$ brick aggregate and $80 \%$ stone aggregate, gives the highest Marshall stability. This bituminous concrete mix shows considerable improvement in various mechanical properties of the mix as compared to the other mixes.
\end{abstract}

\section{Introduction}

Road building activities have recently been highly intensified in India with the implementation of Pradhan Mantri Gram Sadak Yojona (PMGSY) scheme and Golden Quadrilateral as well as Bharat Nirman schemes over length and breadth of the country. One of the major problems, confronted by many states in India, is the nonavailability of stone aggregates for construction of roads. In the North-Eastern part of India, especially, Tripura, Mizoram, and Manipur, stones are not locally available. The required natural stone aggregate is brought from other states of India all the time to meet the demand of these states. Therefore, with a view to minimizing the dependents on other regions for a constant supply of stone aggregate, it has become necessary to investigate into the possible applications of alternative materials for the construction of roads as a full or partial substitute of stone aggregate. One of the promising and efficient ways is to use over-burnt brick aggregates (OBBA) in road construction.

Bricks, produced by burning the moulded soil, contain an adequate percentage of clay. Approximately $13 \%$ of bricks, produced by the process of burning, are overburnt due to uncontrolled distribution of temperature in the kiln during manufacture. These over-burnt bricks have no use in cement concrete preparations and, therefore, are considered as wastage. In addition, the manufacturers of brick often face problem regarding the disposal of this enormous waste overburnt bricks. Over-burnt bricks have $7-10 \%$ less abrasion loss and $6-9 \%$ less water absorption than the first class bricks. Over-burnt bricks have a maximum Los-Angeles Abrasion value of $30 \%$ which is within limit and can be used in base course as aggregate [1]. The inordinate scarcity of natural stones and the exorbitant cost of the imported natural stones have accelerated the necessity of finding out locally available materials for using as a coarse aggregate, in some remote places of the North-Eastern region of India. A Marshall stability of $14.0 \mathrm{kN}, 12.5 \mathrm{kN}$, and $12.3 \mathrm{kN}$, respectively, for fresh stone, fresh brick, and waste brick is observed. These are greater in stability than the minimum value in regard to the point of Marshall stability according to standards [2]. Bricks are highly porous ceramic material and have high water absorption capacity. The effort of compaction influences the resistance to permanent deformation characteristics of those materials prepared with brick aggregate. There is a decrease in 
strength varying from $20 \%$ to $30 \%$ in case of both coarse and fine crushed bricks depending on the degree of substitution $[3,4]$. Dense graded picked brick aggregate bituminous mixes with higher percentage of bitumen content are also good as compared to crushed stone aggregate bituminous mixes for use in the base course of bituminous concrete pavement [5].

Only OBBAs cannot be used in bituminous concrete mix as these are weak. But bricks are easily and locally available materials. On the other hand, mechanical properties of bituminous concrete with stone are much more superior to OBBA. But in many places stone aggregates are not locally available. Now in this situation brick-stone mix will be the better alternative as a solution.

In the present study, brick-stone aggregates have been mixed in different ratios (by weight) such as $20: 80,40: 60$, $60: 40$, and $80: 20$, respectively. Standard tests like specific gravity, water absorption, Los-Angeles Abrasion, Impact, Marshall, Indirect Tensile Strength, stripping, rutting, and fatigue test have been carried out in the laboratory. The objective of the study is to characterize the mechanical properties of brick-stone bituminous concrete.

\section{Material for This Study}

The constituents of bituminous concrete are coarse aggregate, fine aggregate, filler material, and bitumen. The materials, used for this study, are over-burnt bricks and crushed stone as coarse aggregate and VG 30 grade of bitumen as binder material. Stone dust is used as filler material. Over-burnt distorted bricks have been collected from the local brick manufacturing kilns. Bricks are hammered into pieces and thereafter the pieces are crushed to the desired sizes by a laboratory crusher. Approximately 2 tons of over-burnt brick aggregates and the same amount of stone aggregates have been used in this work to study the physical and mechanical properties.

\section{Material Properties}

The materials used for this study are coarse aggregate, fine aggregate, filler material, and binder. Crushed stone and brick aggregates are also used as coarse aggregate. All the above-mentioned ingredients are used in the preparation of bituminous concrete mix. The properties of ingredient materials as well as the mix are tested in laboratory.

3.1. Aggregate. The coarse aggregates used for bituminous concrete will necessarily be clean, hard, tough, durable, and uniform quality throughout. The over-burnt brick aggregates (OBBA) and stone aggregates are tested as per ASTM guidelines [6-9]. The coarse aggregate is prepared by mixing OBBA and crushed stone in different ratios (by weight). The physical properties of plain OBBA and the mix are presented in Table 1.

Ministry of Road Transport and Highways (MoRT\&H), 2013, specifies the limiting value of different test results for the properties of coarse aggregate used in the preparation of bituminous concrete. As per MoRT\&H (2013), the Impact value, Los-Angeles Abrasion value, and water absorption of
TABle 1: Properties of aggregate.

\begin{tabular}{lccccc}
\hline \multirow{2}{*}{ Test performed } & OBBA & \multicolumn{5}{c}{ Brick and stone mix } \\
& $20: 80$ & $40: 60$ & $60: 40$ & $80: 20$ \\
\hline $\begin{array}{l}\text { Aggregate Impact value } \\
(\%)\end{array}$ & 36.2 & 27.2 & 29.70 & 34.12 & 35.31 \\
$\begin{array}{l}\text { Los-Angeles Abrasion } \\
\text { value (\%) }\end{array}$ & 46.0 & 33.0 & 37.41 & 40.63 & 42.18 \\
$\begin{array}{l}\text { Water absorption value } \\
(\%)\end{array}$ & 6.6 & 1.78 & 3.55 & 4.90 & 5.24 \\
\begin{tabular}{l} 
Specific gravity \\
\hline
\end{tabular} & 1.89 & 2.46 & 2.24 & 2.16 & 2.07 \\
\hline
\end{tabular}

TABLE 2: Properties of stone dust.

\begin{tabular}{lrc}
\hline Sl. number & Test performed & Test result \\
\hline 1 & Specific gravity & 2.7 \\
2 & Bulk density $\left(\mathrm{kN} / \mathrm{m}^{3}\right)$ & 18.1 \\
\hline
\end{tabular}

Table 3: Properties of bitumen.

\begin{tabular}{lccc}
\hline Sl. number & Test performed & Test result & Acceptable values \\
\hline 1 & Specific gravity & 0.99 & 0.99 (minimum) \\
2 & Penetration $(\mathrm{mm})$ & 83 & $80-100$ \\
3 & Softening point $\left({ }^{\circ} \mathrm{C}\right)$ & 47 & $35-50$ \\
4 & Ductility $(\mathrm{cm})$ & 93 & 75 (minimum) \\
\hline
\end{tabular}

aggregate should not exceed $30 \%, 40 \%$, and $2 \%$, respectively [10]. Also, the specific gravity should be within 2.5-3.0. Limiting values of Impact, abrasion, water absorption, and specific gravity are satisfactory at 20:80 ratio of brick-stone aggregate mix.

3.2. Filler. Mineral fillers contain finely divided mineral matter such as rock dust, slag dust, hydrated lime, hydraulic cement, fly ash, loess, and other suitable mineral materials. Mineral fillers should possess 100 percent of the particles passing $0.60 \mathrm{~mm}, 95$ to 100 percent passing $0.30 \mathrm{~mm}$, and 70 percent passing $0.075 \mathrm{~mm}$. During the preparation of sample, the mineral filler will be sufficiently dried to flow freely. In this study, stone dust has been used as mineral filler. The properties of stone dust, used in this study, are listed in Table 2.

3.3. Bitumen. VG-30 grade of bitumen has been used as binder to prepare the bituminous concrete. The properties of bitumen, used in this study, are presented in Table 3 and compared with the acceptable values mentioned in Indian Standard Codes [11-14].

\section{Marshall Mix Design}

Marshall Test, a stability test, is applicable to hot-mix design of bitumen and aggregates. In India, bituminous concrete mix is commonly designed by Marshall Method. By this method, the resistance to plastic deformation of cylindrical specimen of bituminous mixture is measured $[15,16]$. The test procedure is used in the design and evaluation of 
TABLE 4: Gradation of aggregate for bituminous concrete.

\begin{tabular}{|c|c|c|c|}
\hline Sieve in $\mathrm{mm}$ & \% passing by weight of specimen & Cumulative $\%$ passing & $\%$ of aggregate and mineral filler \\
\hline 19 & 100 & 100 & \multirow{4}{*}{ Coarse aggregate $38 \%$} \\
\hline 13.2 & $90-100$ & 89.5 & \\
\hline 9.5 & $70-88$ & 79.0 & \\
\hline 4.75 & $53-71$ & 62.0 & \\
\hline 2.36 & $42-58$ & 50.0 & \multirow{6}{*}{ Fine aggregate 55\% } \\
\hline 1.18 & $34-48$ & 41.0 & \\
\hline 0.60 & $26-38$ & 32.0 & \\
\hline 0.30 & $18-28$ & 23.0 & \\
\hline 0.15 & $12-20$ & 16.0 & \\
\hline 0.075 & $4-10$ & 7.00 & \\
\hline
\end{tabular}

Mineral filler 7\%.

TABle 5: Design criteria as per MoRT\&H.

\begin{tabular}{lcccccccc}
\hline Test performed & $\begin{array}{c}\text { Minimum } \\
\text { stability } \\
\left.\text { (at } 60^{\circ} \mathrm{C}\right)\end{array}$ & $\begin{array}{c}\text { Flow } \\
(\mathrm{mm})\end{array}$ & $\begin{array}{c}\text { Compaction } \\
\text { level } \\
\text { (both side) }\end{array}$ & Air void & $\begin{array}{c}\text { VMA } \\
(\text { minimum) }\end{array}$ & VFB & $\begin{array}{c}\text { Marshall } \\
\text { Quotient } \\
(\mathrm{kN} / \mathrm{mm})\end{array}$ & $\begin{array}{c}\text { Tensile Strength } \\
\text { Ratio } \\
(\mathrm{minimum})\end{array}$ \\
\hline Results & $9 \mathrm{kN}$ & $2-4$ & 75 & $3-5 \%$ & $10 \%$ & $65-75 \%$ & $2-5$ & $80 \%$ \\
\hline
\end{tabular}

bituminous paving mixes. In this present study, Marshall Test is performed with over-burnt brick and stone aggregate mix. The standard gradation of aggregates in the preparation of the test specimen is followed in this study as per MoRT\&H presented in Table 4.

One of the objectives of the mix design is to find the suitable bitumen content. The Marshall Method is used to determine the optimum bitumen content (OBC). Standard values of Marshall Test results and Tensile Strength Ratio (TSR) as specified by MoRT\&H are presented in Table 5.

Test specimens have been prepared and tested in the laboratory according to MoRT\&H guidelines. From the test results the relationship between Marshall stability, flow value, bulk density, air void (VA), and voids filled with bitumen (VFB) with varying percentages of binder content for brickstone aggregate has been studied. In this present study Marshall samples are prepared with the aggregate containing brick and stone aggregate in the ratio of $20: 80,40: 60,60: 40$, and $80: 20$, respectively. The Marshall Test results, obtained in the laboratory, are listed in Table 6.

The Marshall mix design procedure as specified in ASTM D6927-15 [17] is used for determining the optimum binder content (OBC). The Marshall specimens are prepared by adding $4.5 \%, 5 \%, 5.5 \%$, and $6 \%$ of bitumen (by weight of aggregate), respectively, into the hot aggregate. Three identical specimens for each percentage are fabricated and the average value is reported. For 20:80 mix (brick and stone) the volumetric properties are then determined (as shown in Figure 1) to obtain the optimum binder content, which is found to be $5.45 \%$ (by weight of mix) with $3.96 \%$ air voids, $16.35 \%$ voids in mineral aggregate, and $71 \%$ VFB. Similarly, for other mixes $(40: 60,60: 40$, and $80: 20)$ volumetric properties are determined and tabulated in Table 6.

From Table 6, it is observed that the stability of the mix increases with the increase in percentage of stone aggregate in the mix. At 20:80 mix of brick and stone aggregate the
TABLE 6: Marshall Test results on different aggregate.

\begin{tabular}{lccccc}
\hline \multirow{2}{*}{ Properties } & \multicolumn{5}{c}{ Different ratio of brick-stone mix } \\
& $0: 100$ & $20: 80$ & $40: 60$ & $60: 40$ & $80: 20$ \\
\hline OBC (\%) & 5 & 5.45 & 6.57 & 7.33 & 8.4 \\
Unit weight $\left(\mathrm{kN} / \mathrm{m}^{3}\right)$ & 24.03 & 23.85 & 23.60 & 23.35 & 23.0 \\
Marshall stability (kN) & 14.85 & 13.75 & 13.23 & 12.50 & 10.78 \\
Flow (mm) & 3.35 & 3.44 & 3.56 & 3.70 & 3.77 \\
\% VA & 3.33 & 3.96 & 4.25 & 4.49 & 4.78 \\
\% VMA & 15.01 & 16.35 & 17.78 & 18.91 & 20.10 \\
\% VFB & 69.5 & 71 & 76 & 78 & 81 \\
$\begin{array}{l}\text { Marshall Quotient } \\
\text { (kN/mm) }\end{array}$ & 4.13 & 3.99 & 3.72 & 3.37 & 2.85 \\
\hline
\end{tabular}

stability value reaches the highest point of $13.75 \mathrm{kN}$. Hence, $20: 80$ mix is considered as the most suitable mix for further performance study. However, mixes with very high Marshall stability values and low flow values are not desirable as the pavements constructed, with such mixes, may be brittle and may likely develop cracks due to heavy moving loads, if the pavement components permit relatively high deflection values. This is examined by Marshall Quotient value of the mix. In 20 : 80 mix ratio of brick and stone aggregate, Marshall Quotient value is also within the limit [18].

\section{Performance Evaluation}

Performance of the prepared mix is evaluated in the lab in terms of some laboratory test.

\subsection{Test Procedure Followed}

5.1.1. Indirect Tensile Strength Test. The Indirect Tensile Strength (ITS) test is used to measure the tensile strength 

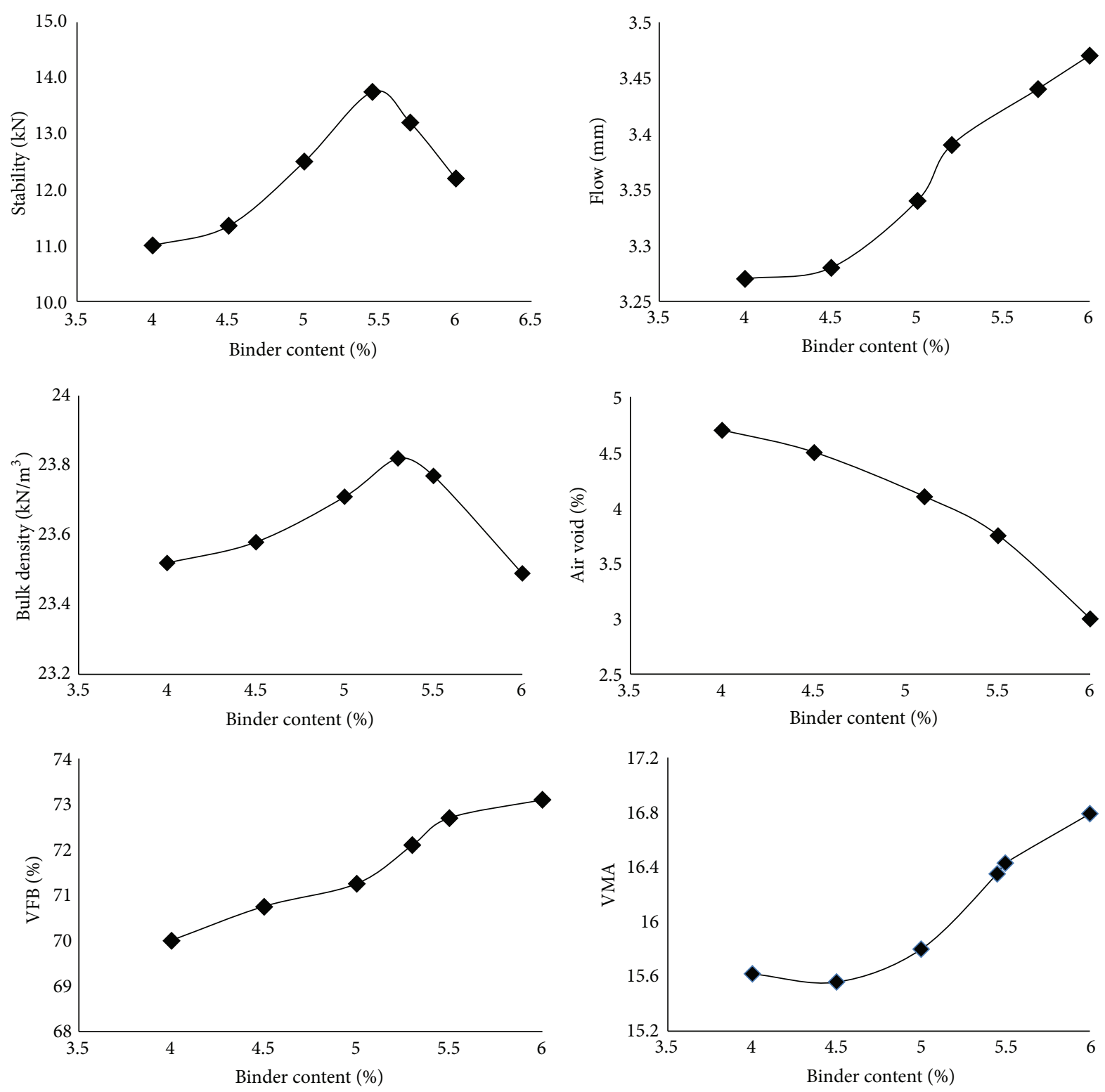

FIGURE 1: Volumetric properties of bituminous concrete mix (using $20: 80$ ratio of brick-stone aggregate mix) at binder content versus stability, flow, air voids, bulk density, voids filled with bitumen, and void in mineral aggregate.

of the bituminous concrete which can be used to assess the fatigue behavior. The standard procedure as per ASTM D 6931 is followed to prepare the sample for the test as well as measure the failure loads. ITS provides a measure of the tensile strength of the bituminous mixes. The test is conducted on the conditioned and unconditioned samples. The sample is tested in the Marshall stability testing equipment [19].

The failure load is measured and the ITS is calculated from the following equation:

$$
S_{T}=\frac{2 F}{3.14(h d)}
$$

where $S_{T}$ is tensile strength $\left(\mathrm{N} / \mathrm{mm}^{2}\right), F$ is peak value of the vertical load (N), $h$ is height of the specimen in $\mathrm{mm}$, and $d$ is diameter of the specimen in $\mathrm{mm}$.
The indirect Tensile Strength Ratio (TSR) is determined with the following equation:

$$
\operatorname{TSR}=100\left(\frac{S_{\text {cond }}}{S_{\text {uncond }}}\right)
$$

where $S_{\text {cond }}$ is average ITS of the wet specimen and $S_{\text {uncond }}$ is average ITS of the dry specimen.

Bituminous pavement surface can exhibit distress due to fatigue. It is caused by tensile strains generated in the pavement not only by traffic loading but also by temperature variations. If the tensile strength is more and the Tensile Strength Ratio is within the permissible limit, in another way it can be said that bitumen concrete mix is safe against fatigue. 
5.1.2. Stripping Value Test. Stripping value test implies the determination of binding strength of aggregate and bitumen. Standard guideline as specified by IS: 6241-1971 is followed here to complete the test [20]. $200 \mathrm{gm}$ of clean oven-dried aggregates passing $20 \mathrm{~mm}$ sieve and retained on $12.5 \mathrm{~mm}$ sieve is heated up to $150^{\circ} \mathrm{C}$ and mixed with $5 \%$ bitumen by weight of aggregate which is preheated to $160^{\circ} \mathrm{C}$ before the preparation of mix. It is tested by immersing bitumen coated aggregate in water for $24 \mathrm{~h}$ at $40^{\circ} \mathrm{C}$. When the bitumen coated aggregate is immersed in water, the water penetrates into the pores and the voids of the aggregate, resulting in the peeling of bitumen. After a period of $24 \mathrm{~h}$, the stripping is observed and the percentage of stripping is noted [21].

5.1.3. Rutting Studies. Rutting is a longitudinal depression on groove in the wheel tracks. The ruts are usually of the width of wheel path. Pavement rutting not only decreases the service life of the roads but also creates danger for the safety of road users. Rutting characteristics are studied using immersion wheel tracking device. Wheel tracking test is widely used for evaluating the rutting potential of pavements. In this method, a steel wheel with solid rubber tire intended for to-andfro motion over the specimen of bituminous surface of size $600 \mathrm{~mm} \times 200 \mathrm{~mm} \times 50 \mathrm{~mm}$ is employed and the rutting depth at 8,000 passes is determined [22].

5.1.4. Fatigue Life Test. Repeated load test is conducted using fatigue testing machine developed by Geotran, New Delhi. An attempt has been made to study the performance of bituminous concrete with $20: 80$ and $80: 20$ brick-stone aggregate mix under the applied load as $2 \mathrm{kN}, 3 \mathrm{kN}$, and $4 \mathrm{kN}$ and frequency $5 \mathrm{~Hz}$ with sinusoidal type of waveform applied at temperature of $35^{\circ} \mathrm{C}-37^{\circ} \mathrm{C}[23,24]$. Three specimens are tested for each case.

5.1.5. Resilient Modulus Test. Resilient modulus (RM) of bituminous concrete mix is an important parameter for flexible pavement design and evaluation. It is defined as the ratio of the repeated stress to the corresponding resilient strain. The total resilient modulus is calculated from the following equation:

$$
E_{\mathrm{RT}}=\frac{P\left(V_{\mathrm{RT}}+0.27\right)}{t \Delta \mathrm{HT}},
$$

where $P$ is the repeated load in $\mathrm{N}, V_{\mathrm{RT}}$ is the total Resilient Poisson's ratio generally taken as $0.35, t$ is the thickness of specimen in $\mathrm{mm}$, and $\Delta \mathrm{HT}$ is the total recoverable horizontal deformation in $\mathrm{mm}$. The test is performed according to ASTM D 7369-11 [25].

\subsection{Test Results}

5.2.1. Results of Indirect Tensile Strength Test. The test results of the present study are noted in Table 7. It is noticed that the Indirect Tensile Strength (ITS) is highest when the aggregate ratio is $20: 80$ (brick: stone) and the value is $1.30 \mathrm{~N} / \mathrm{mm}^{2}$ and corresponding Tensile Strength Ratio (TSR) is $83.85 \%$ which is acceptable (as per Table 5). Thus, 20:80 ratio of aggregate
TABle 7: Indirect Tensile Strength Test results.

\begin{tabular}{lcccc}
\hline \multirow{2}{*}{ Sl. number } & \multirow{2}{*}{ Mix ratio } & \multicolumn{2}{c}{ Indirect Tensile Strength } & \multirow{2}{*}{ TSR (\%) } \\
& & Unconditioned & Conditioned & \\
\hline 1 & $20: 80$ & 1.30 & 1.09 & 83.85 \\
2 & $40: 60$ & 1.12 & 0.89 & 79.46 \\
3 & $60: 40$ & 0.83 & 0.59 & 71.08 \\
4 & $80: 20$ & 0.72 & 0.50 & 69.44 \\
\hline
\end{tabular}

TABLE 8: Stripping value test results.

\begin{tabular}{lcc}
\hline Sl. number & Mix ratio (brick: stone) & Stripping (\%) \\
\hline 1 & $20: 80$ & 2 \\
2 & $40: 60$ & 4 \\
3 & $60: 40$ & 5.5 \\
4 & $80: 20$ & 8 \\
\hline
\end{tabular}

mix (brick : stone) for bituminous concrete mix is safe against fatigue.

5.2.2. Results of Stripping Value Test. In this study the test is conducted for different mixes of brick-stone aggregate. The results are displayed in Table 8 . It is observed that the stripping value is least in case of $20: 80$ ratio of brick-stone mix. It satisfies the acceptable value (as per Table 5). Hence, $20: 80$ ratio for bituminous concrete shows a better binding strength with bitumen even when it is subjected to the worst moisture content.

5.2.3. Results of Rutting Studies. In present study the stress that the wheel applies on the specimen is $0.70 \mathrm{MPa}$. Two LVDT (Linear Variable Differential Transducers) are fitted to the axle of the rubber wheel to monitor the rut depth. The output of the LVDT is connected to computer. Dedicated software monitors the rut depth and plots the graph for number of passes versus rut depth. The wheel tracking results are shown in Figure 2. The rutting is found lower in case of bituminous concrete mix containing $20: 80$ ratio $(5.3 \mathrm{~mm})$ in comparison to the $80: 20$ ratio $(7.1 \mathrm{~mm})$.

5.2.4. Results of Fatigue Life Test. The test result shows that the fatigue life of bituminous concrete with $20: 80$ is much higher than that of bituminous concrete with $80: 20$ brickstone aggregate mix for equal tensile strain. This is due to the hardness of aggregate mix as stone percentage is more in $20: 80$ ratio. Figure 3 indicates that, for a given tensile strain $\varepsilon_{t}$ of $200 \times 10^{-6}$, the corresponding fatigue life of bituminous concrete of $20: 80$ and $80: 20$ brick-stone aggregate is 534 and 370 , respectively. Thus, it can be concluded that the fatigue life of bituminous concrete mix with 20:80 ratio increases by factor of 1.44 . This clearly indicates that BC mix with 20:80 ratio can tolerate high strain and takes more number of repetitions prior to failure. The present investigation conclusively proves that bituminous concrete mixes with $20: 80$ ratio can be expected to have much longer 


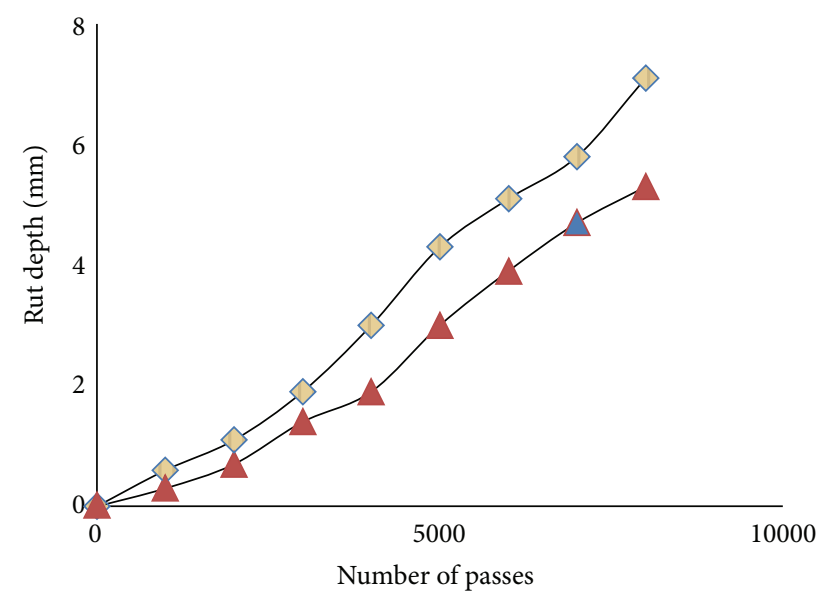

$80: 20 \mathrm{mix}$

$20: 80 \mathrm{mix}$

FIgURE 2: Rut depth versus number of passes.

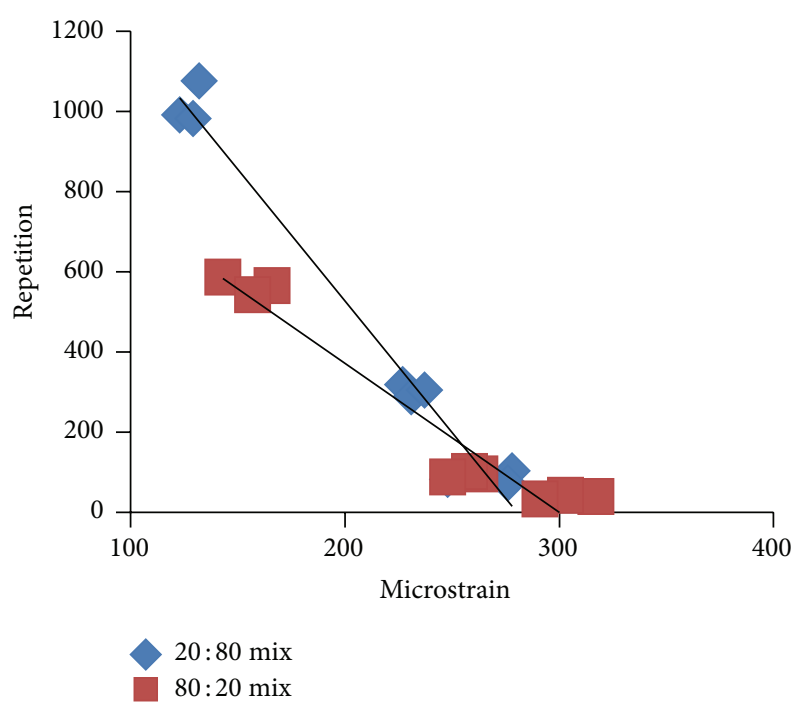

FIGURE 3: Tensile strain versus number of repetitions.

fatigue life than the bituminous concrete mix with $80: 20$ brick-stone aggregate mix.

5.2.5. Results of Resilient Modulus Test. The test is performed at different temperatures such as $5^{\circ} \mathrm{C}, 25^{\circ} \mathrm{C}, 35^{\circ} \mathrm{C}$, and $45^{\circ} \mathrm{C}$. The test results for resilient modulus test, obtained in the study, are shown in Figure 4.

It is seen that RM value decreases with increase in temperature from $5^{\circ} \mathrm{C}$ to $45^{\circ} \mathrm{C}$. At $5^{\circ} \mathrm{C}$, the $\mathrm{RM}$ value of $20: 80$ mix is 0.63 times higher whereas at $45^{\circ} \mathrm{C}$ it is about 1.32 times higher as compared to $80: 20$ brick-stone aggregate mix. This shows that 20:80 mix is more suitable for hot climate. Moreover, MR values containing 20\% brick and $80 \%$ stone at all specified temperatures are higher as compared to $80: 20$ brick-stone aggregate mix.

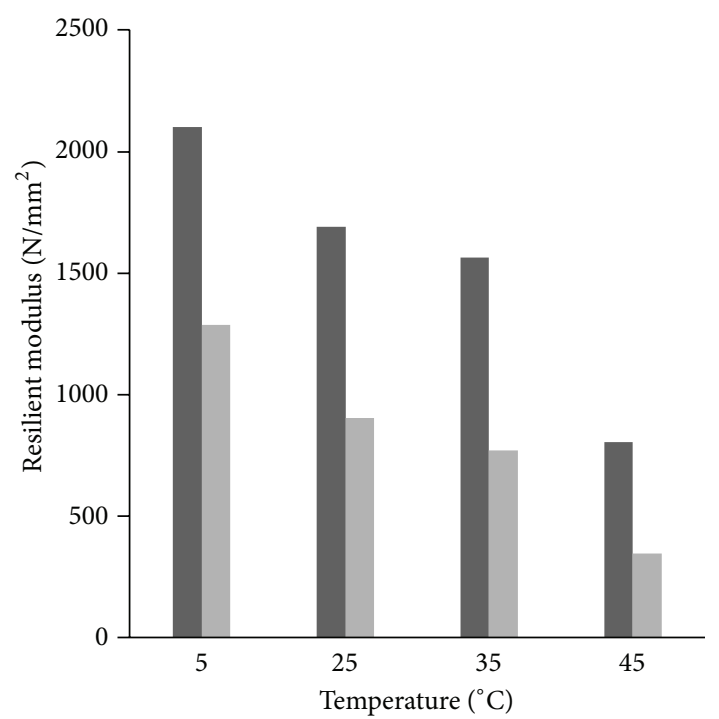

$20: 80 \mathrm{mix}$

$80: 20$ mix

FIgURE 4: Resilient modulus values for the mix with $20: 80$ aggregate (brick: stone).

\section{Conclusion}

On the basis of analysis of results, obtained in the present investigations, the following conclusions are drawn:

(1) The increase of stone aggregate in the brick-stone aggregate mix significantly reduces the value of Impact, Los-Angeles Abrasion, and water absorption but increases the specific gravity. Limiting value of Impact, abrasion, water absorption, and specific gravity is satisfactory at $20: 80$ ratio of brick-stone aggregate mix.

(2) The maximum Marshall stability value is obtained in case of $20: 80$ ratio of brick-stone aggregate mix. The stability is increased by $28 \%$ in case of $20: 80$ ratio as compared to $80: 20$ ratio of brick-stone aggregate mix. The Marshall flow value is also within the limits (3-5 mm) for this mix. Moreover, the Marshall Quotient is also within the range of tolerance as it shows that the $20: 80$ ratio of brick-stone aggregate, prepared for bituminous concrete mix, is better and more suitable for flexible pavement construction.

(3) Selection of $\mathrm{OBC}$ is a delicate balancing act in which there are a number of variables. A balance is to be maintained in such a way that the specified limits, recommended in the code of practice, are simultaneously satisfied. In this study $5.45 \%$ bitumen content at $20: 80$ ratio of brick-stone aggregate mix is chosen as the optimum bitumen content and it also satisfies all the acceptable ranges.

(4) ITS value increases with the increasing uses of stone in the mix as it reaches a peak value at a ratio of $20: 80$. ITS value of $20: 80$ ratio increases by $80 \%$ and 
$118 \%$ compared to $80: 20$ mix for unconditioned and conditioned samples, respectively. Tensile Strength Ratio is also within the limit for 20:80 mix. So bituminous concrete mix with 20:80 ratio is safe against fatigue.

(5) Stripping value reduces with the increase in the percentage of stone in the aggregate mix. Striping value in case of $20: 80 \mathrm{mix}$ is $2 \%$ which has higher strip resistant.

(6) Test results indicate that the bituminous concrete mix with $20: 80$ ratio is less susceptible to rut deformation as compared to bituminous concrete mix with $80: 20$ brick-stone aggregate mix. It is observed that total depression depth with the 20:80 mix has reduced $24 \%$ as compared to $80: 20$ brick-stone aggregate mix.

(7) It is noticed that RM values decrease with increase in temperature from $5^{\circ} \mathrm{C}$ to $45^{\circ} \mathrm{C}$. The results for $\mathrm{RM}$ obtained at low and high temperatures show that $20: 80$ ratio mix has high $\mathrm{RM}$ value compared to the $80: 20$ mix.

(8) It is observed that the fatigue life of bituminous concrete mix with 20:80 brick-stone aggregate mix increases by a factor of 1.44 at $35^{\circ} \mathrm{C}$ to $37^{\circ} \mathrm{C}$ temperature at tensile strain level compared to $80: 20$ brickstone aggregate mix.

Thus, the bituminous concrete with 20:80 brick-stone aggregate mix shows considerable improvement in various mechanical properties of mix compared to other brick-stone aggregate mix ratios, namely, $40: 60,60: 40$, and $80: 20$.

\section{Conflict of Interests}

The authors declare that there is no conflict of interests regarding the publication of this paper.

\section{References}

[1] A. R. Mazumder, A. Kabir, and N. Yazdani, "Performance of over burnt distorted bricks as aggregates in pavement works," Journal of Materials in Civil Engineering, vol. 18, no. 6, pp. 777785, 2006.

[2] H. M. Rasel, M. A. Sobhan, and M. N. Rahman, "Performance evaluation of brick chips as coarse aggregate on the properties of Bituminous mixes," S-JPSET, vol. 2, no. 2, pp. 37-46, 2011.

[3] F. D. C. Leite, R. D. S. Motta, K. L. Vasconcelos, and L. Bernucci, "Laboratory evaluation of recycled construction and demolition waste for pavements," Construction and Building Materials, vol. 25, no. 6, pp. 2972-2979, 2011.

[4] F. Debieb and S. Kenai, "The use of coarse and fine crushed bricks as aggregate in concrete," Construction and Building Materials, vol. 22, no. 5, pp. 886-893, 2008.

[5] M. D. Lanham, M. A. Sobhan, and M. Zakaria, "Experimental behaviour of bituminous macadam mixes with brick aggregate," Journal of Civil Engineering, vol. 29, no. 1, pp. 115-123, 2001.

[6] ASTM, "Standard test method for density, relative density (specific gravity) and absorption of coarse aggregate," ASTM C127-12, ASTM International, 2012.
[7] ASTM C535:12, Standard Test Method for Resistance to Degradation of Large Size Coarse Aggregate by Abrasion and Impact in the Los-Angeles Machine, 2012.

[8] ASTM, "Standard test method for resistance to degradation of small size coarse aggregate by abrasion and impact in the LosAngeles machine," ASTM C131-06, ASTM International, West Conshohocken, Pa, USA, 2006.

[9] MoRT\&H, Specification of Ministry of Road Transport and Highways, Specification for Roads and Bridge Works, IV Revision, Indian Roads Congress, New Delhi, India, 2013.

[10] ASTM, "Standard test method for Sieve analysis of fine and coarse aggregate," ASTM C136-06, ASTM International, 2006.

[11] IS, "Methods for testing tar and bituminous materials, determination of ductility," IS 1208: 1978, Bureau of Indian Standards, 1978.

[12] Bureau of Indian Standards, "Methods for testing tar and bituminous materials, determination of penetration," IS 1203:1978, Bureau of Indian Standards, New Delhi, India, 1978.

[13] Bureau of Indian Standard, "Methods for testing tar and bituminous materials, determination of specific gravity," IS 1202:1978, Bureau of Indian Standard, 1978.

[14] IS 1205, Bureau of Indian Standard, Methods for Testing Tar and Bituminous Materials, Determination of Softening Point, India, 1978.

[15] Bureau of Indian Standards, "Indian standard paving bitumen-specification, 2nd revision," IS 73:1992, Bureau of Indian Standards, 1992.

[16] ASTM International, "Standard test method for marshall stability and flow of asphalt mixtures," ASTM D6931-12, ASTM International, West Conshohocken, Pa, USA, 2012.

[17] ASTM, "Standard test method for marshall stability and flow of bituminous mixtures," ASTM D6927-06, ASTM International, West Conshohocken, Pa, USA, 2006.

[18] R. S. Kumar, Highway Engineering, Universities Press (India) Pvt. Ltd, 2011.

[19] ASTM International, "Standard test method for indirect tensile (IDT) strength of bituminous mixtures," ASTM D6931-12, ASTM International, West Conshohocken, Pa, USA, 2012.

[20] Bureau of Indian Standards, "Methods for test for determination of stripping value of road aggregates," IS 6241:1971, Bureau of Indian Standards, New Delhi, India, 1971.

[21] F. Moghadas Nejad, A. R. Azarhoosh, G. H. Hamedi, and M. J. Azarhoosh, "Influence of using nonmaterial to reduce the moisture susceptibility of hot mix asphalt," Construction and Building Materials, vol. 31, pp. 384-388, 2012.

[22] V. B. Kakade and M. A. Reddy, "Effect of type and quantity of binder on rutting characteristics of bituminous mix," Indian Highways, vol. 42, no. 3, pp. 8-14, 2014.

[23] X. Shu, B. Huang, and D. Vukosavljevic, "Laboratory evaluation of fatigue characteristics of recycled asphalt mixture," Construction and Building Materials, vol. 22, no. 7, pp. 1323-1330, 2008.

[24] G. G. Al-Khateeb and K. A. Ghuzlan, "The combined effect of loading frequency, temperature and stress level on the fatigue life of asphalt paving mixtures using the IDT test configuration," International Journal of Fatigue, vol. 59, pp. 254-261, 2014.

[25] ASTM International, "Standard test method for determining the resilient modulus of bituminous mixtures by indirect tension test," ASTM D7369-11, ASTM International, West Conshohocken, Pa, USA, 2011. 

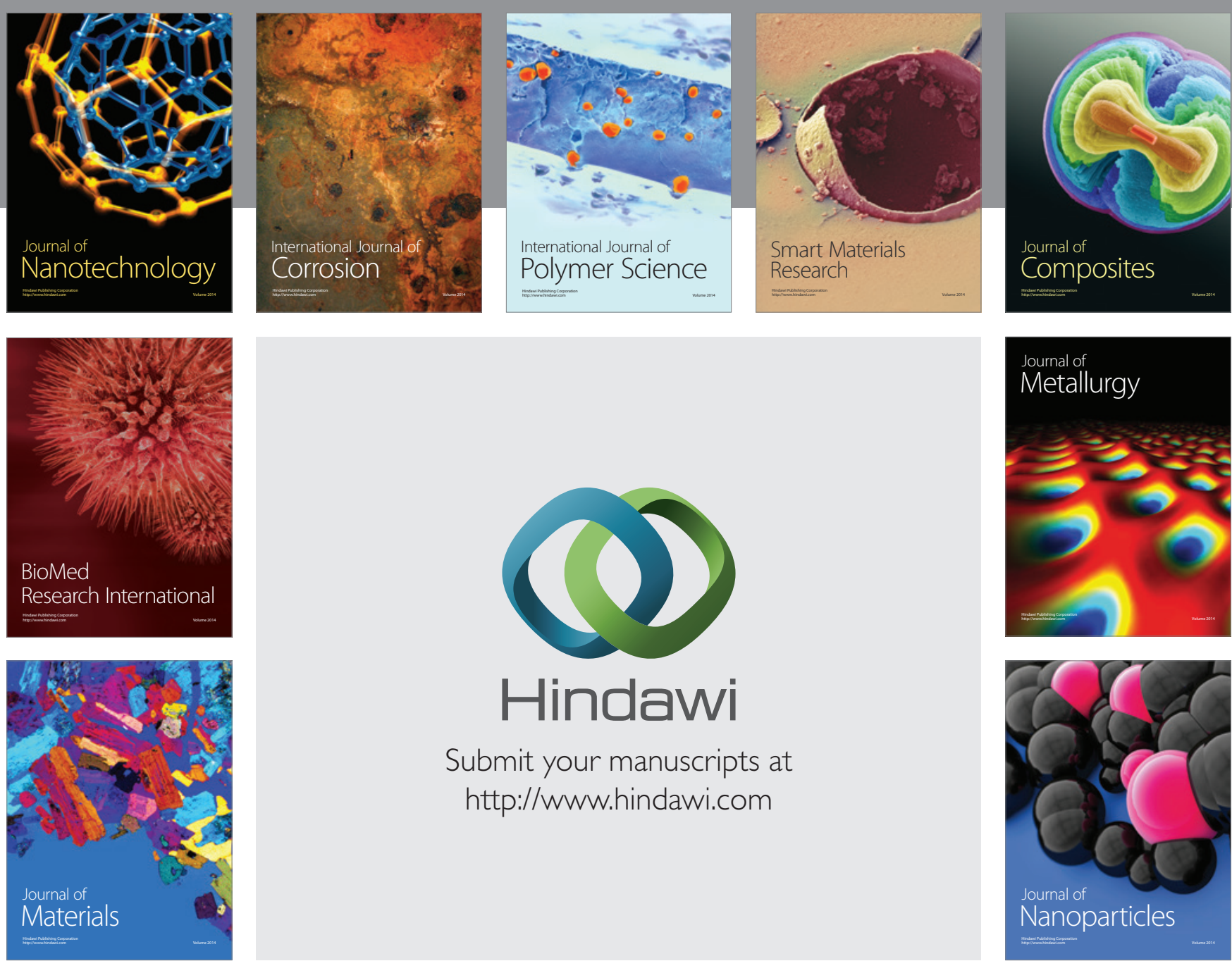

\section{Hindawi}

Submit your manuscripts at

http://www.hindawi.com

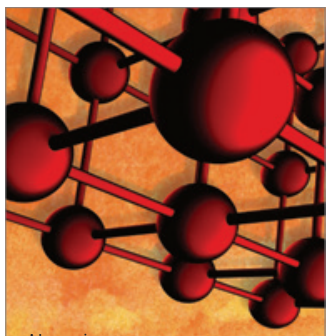

Materials Science and Engineering
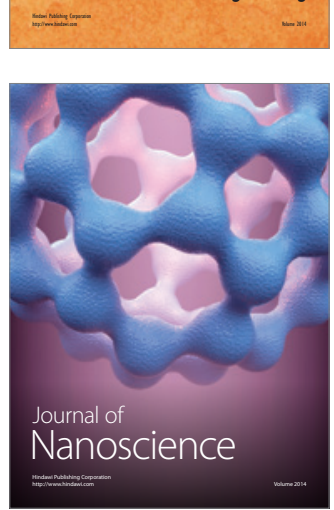
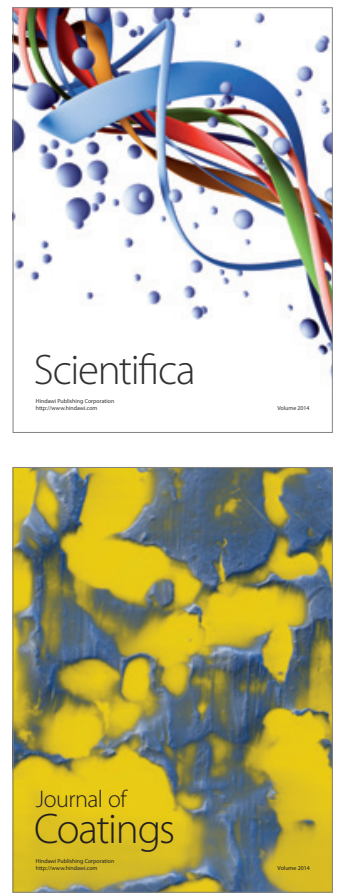
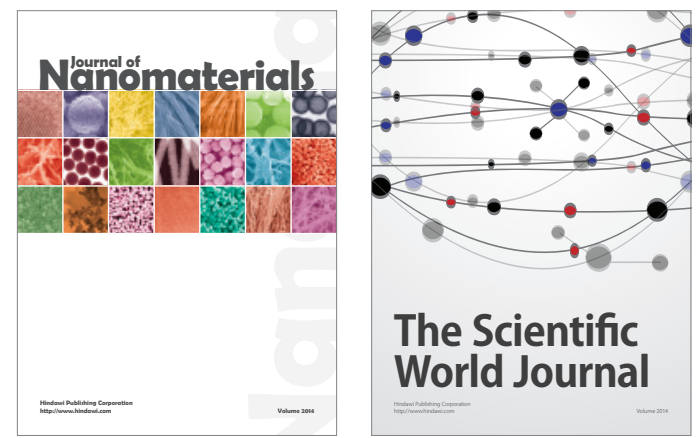

The Scientific World Journal
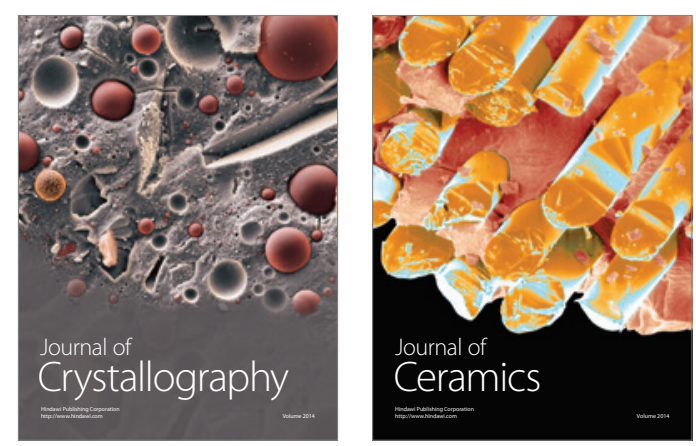
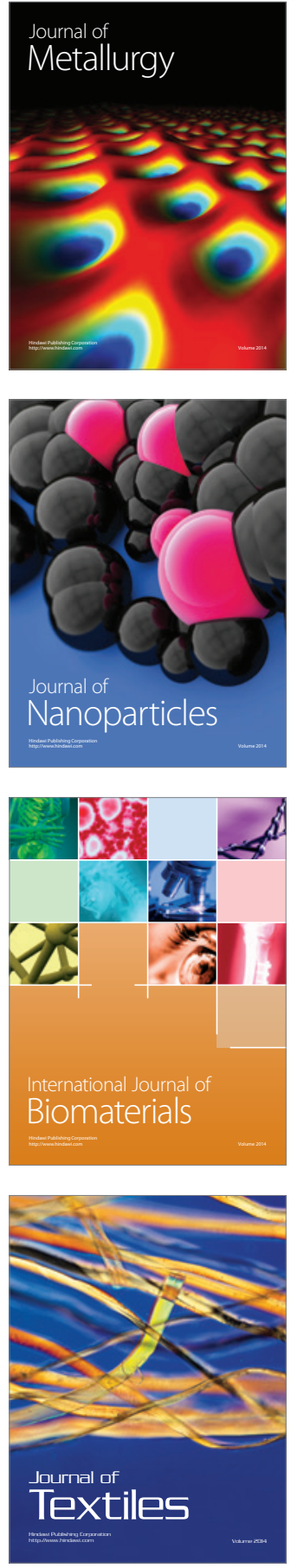